\title{
The risk of diabetes development in long-term observation of patients with acute hyperglycaemia during myocardial infarction
}

\author{
Michał Terlecki, Leszek Bryniarski, Agnieszka Bednarek, Maryla Kocowska, Kalina Kawecka-Jaszcz, \\ Danuta Czarnecka \\ $1^{\text {st }}$ Department of Cardiology, Interventional Electrocardiology, and Hypertension, Jagiellonian University, Medical College, Krakow, Poland
}

\begin{abstract}
Background: Acute hyperglycaemia in patients with myocardial infarction (MI) is an unfavourable predictive factor. However, there are limited data regarding the relationship between acute hyperglycaemia and the incidence of new onset diabetes in long-term observation.

Aim: We studied the relationship between admission glycaemia in patients with $\mathrm{Ml}$ and the future development of diabetes.

Methods: In 190 patients admitted during 2004-2007 with MI, diabetes was excluded on the basis of oral glucose tolerance test performed at the end of hospitalisation. Patients were divided into three groups according to admission glucose level: G1 < $7.8 \mathrm{mmol} / \mathrm{L}$ (< $140 \mathrm{mg} / \mathrm{dL}) ; \mathrm{G} 2: 7.8-11.0 \mathrm{mmol} / \mathrm{L}(140-199 \mathrm{mg} / \mathrm{dL}) ;$ and G3 $\geq 11.1 \mathrm{mmol} / \mathrm{L}(\geq 200 \mathrm{mg} / \mathrm{dL})$.

Results: The groups consisted of 80 (42.1\%), 94 (49.5\%), and 16 (8.4\%) patients, respectively for G1, G2, and G3. The mean age was $61.3 \pm 11.3$ years. ST-segment elevation $\mathrm{Ml}$ was diagnosed in $158(83.2 \%)$ patients and non-ST-segment elevation $\mathrm{MI}$ in $32(16.8 \%)$ patients. A total of 15 cases (7.9\% of the study group) of newly diagnosed diabetes mellitus were registered during a mean follow-up of $48.2 \pm 13.9$ months. Higher incidence of new diabetes diagnosis was noticed in patients with higher glucose level on admission (5.0\% vs. $7.4 \%$ vs. $25.0 \%$, respectively; $p=0.0249)$. Regression analysis showed two independent risk factors of diabetes development in the observational period: admission glucose level considered as a continuous variable with odds ratio $(\mathrm{OR}) 1.2(95 \% \mathrm{Cl} 1.0-1.4, \mathrm{p}=0.03)$ and occurrence of impaired fasting glucose with OR 3.6 (95\% Cl 1.0-12.0, $\mathrm{p}=0.04)$.

Conclusions: Patients with acute hyperglycaemia during $\mathrm{MI}$ are more likely to have diabetes in future. This group of patients requires close monitoring of glucose metabolism after $\mathrm{MI}$.
\end{abstract}

Key words: hyperglycaemia, myocardial infarction, diabetes

Kardiol Pol 2015; 73, 8: 606-612

\section{INTRODUCTION}

Acute hyperglycaemia is a transient increase in blood glucose level and reflects the response of the human body to stress such as myocardial infarction (MI) or stroke. Increased blood glucose level occurs regardless of previous diagnosis of diabetes and may be associated with normal glycated haemoglobin $\left(\mathrm{HbA}_{1 \mathrm{C}}\right)$ values. In acute coronary syndrome (ACS) acute hyperglycaemia is found in all clinical types (ST-segment elevation MI [STEMI], non-ST-segment elevation MI [NSTEMI], and unstable angina) [1].
The mechanisms underlying the development of acute hyperglycaemia are still unclear. It might be the effect of a systemic reaction to stress (hypoxia, hypotension, local cardiomyocytes damage, pain, fear), which releases a process directed toward short-term optimisation of cardiovascular function [2]. Then it leads to hormonal changes causing blood glucose level increase [3]. Other possible causes of acute hyperglycaemia in the acute phase of MI could be previously undiagnosed glucose metabolism disorders. In normal conditions, insufficient insulin secretion by pancreatic beta

\section{Address for correspondence:}

Maryla Kocowska, MD, $1^{\text {st }}$ Department of Cardiology, Interventional Electrocardiology, and Hypertension, Jagiellonian University, Medical College, ul. Kopernika 17 , 31-501 Kraków, Poland, e-mail: marylak@gmail.com Received: 11.01.2014 Accepted: 26.02.2015

Copyright (C) Polskie Towarzystwo Kardiologiczne 
cells or hyperinsulinaemia, are subtle, compensated, and asymptomatic, but in severe stress reaction, when it is impossible to compensate escalated hormonal changes, it leads to the development of hyperglycaemia. A similar mechanism of acute hyperglycaemia is found in patients with previously diagnosed diabetes mellitus where hormonal storm associated with cardiomyocyte damage during ischaemia leads to impairment of the endogenous mechanism to compensate for glucose level.

Acute hyperglycaemia in patients with $\mathrm{MI}$ is an unfavourable predictive factor in short- and long-term observation [4-10]. However, there are limited data regarding the relationship between acute hyperglycaemia in subjects with ACS and the incidence of new onset diabetes in long-term observation.

\section{METHODS}

\section{Study population}

The study involved patients without previously known diabetes, who were selected for an urgent invasive diagnosis of ischaemic heart disease and were hospitalised due to $\mathrm{MI}$ between 2004 and 2007 in the $1^{\text {st }}$ Department of Cardiology and Hypertension of the University Hospital in Krakow. Initially, the study recruited 272 patients who agreed to participate. In all subjects admission glycaemia was measured. We evaluated demographic data, angiographic parameters, echocardiographic changes, and selected laboratory measurements (maximum levels of troponin I and creatine kinase, lipidogram, glucose level on admission, creatine, and glomerular filtration rate). Patients were also assessed for the presence of the following risk factors: smoking status (a person who smoked until the hospitalisation and/or control visit was defined as a smoker), obesity (body mass index $>30 \mathrm{~kg} / \mathrm{m}^{2}$ ), hypertension (systolic pressure $\geq 140 \mathrm{~mm} \mathrm{Hg}$ and/or diastolic pressure $\geq 90 \mathrm{~mm} \mathrm{Hg}$ or diagnosed previously), and hypercholesterolaemia (total cholesterol level $\geq 4.5 \mathrm{mg} / \mathrm{dL}$ or low density lipoprotein cholesterol $>2.5 \mathrm{mg} / \mathrm{dL}$ ). Left ventricular ejection fraction (LVEF) was assessed using Simpson's or Teichholz's method during echocardiography (HP Sonos 5500). The STEMI was defined as the presence of symptoms of ischaemia, persistent ST segment elevation at least in two contiguous leads, or new left bundle branch block in electrocardiogram (ECG) with concomitant rise of cardiac biomarkers [11]. NSTEMI was defined as the presence of symptoms of ischaemia, rise of cardiac biomarkers, without new ST segment elevation, in at least two contiguous leads in ECG [12].

The metabolic syndrome was defined according to the United States National Cholesterol Education Program Adult Treatment Panel III (2001) as the presence of at least three of the following: central obesity: waist circumference $\geq 102 \mathrm{~cm}$ (male), $\geq 88 \mathrm{~cm}$ (female); dyslipidaemia: triglycerides $\geq 1.7 \mathrm{mmol} / \mathrm{L}(150 \mathrm{mg} / \mathrm{dL})$; high density lipoprotein cholesterol $<40 \mathrm{mg} / \mathrm{dL}$ (male), $<50 \mathrm{mg} / \mathrm{dL}$ (female); blood pressure $\geq 130 / 85 \mathrm{~mm} \mathrm{Hg}$ (or treated hypertension); or fasting plasma glucose $\geq 100 \mathrm{mg} / \mathrm{dL}$ (5.6 mmol/L) [13].

\section{Diabetes diagnosis}

During hospitalisation diabetes diagnosis was made according to guidelines for diabetes diagnosis of the European Association for the Study of Diabetes (EASD) and Polish Diabetes Association (PDA), i.e. fasting plasma glucose in two consecutive days at least $126 \mathrm{mg} / \mathrm{dL}(7.0 \mathrm{mmol} / \mathrm{L})$ or symptoms such as increased thirst, polyuria, weakness, and accidental glycaemia at least $200 \mathrm{mg} / \mathrm{dL}$ (11.1 mmol/L), or glucose level within $120 \mathrm{~min}$ after 75 -g oral glucose load at least $200 \mathrm{mg} / \mathrm{dL}$ (11.1 mmol/L). Impaired fasting glucose (IFG) was diagnosed if the concentration of fasting glucose was in the range of 100-125 mg/dL (5.6-6.9 mmol/L). Diagnosis of impaired glucose tolerance (IGT) was made if within $120 \mathrm{~min}$ of oral glucose tolerance test (OGTT) the glucose level was 140-199 mg/dL (7.8-11.1 mmol/L) [14, 15].

To exclude undiagnosed diabetes all patients underwent OGTT after acute phase of ACS (fourth day of hospitalisation or later). During hospitalisation 13 patients died, and diabetes was diagnosed in 69 patients - this group was excluded from further observation. Finally, 190 patients were enrolled into the study, with mean age $61.3 \pm 11.3$ years; $152(80.0 \%)$ were men. STEMI was diagnosed in 158 (83.2\%) subjects, and in 32 (16.8\%) patients NSTEMI was found. Participants were categorised on the basis of admission glycaemia into three groups: G1 (admission glycaemia $<140 \mathrm{mg} / \mathrm{dL}$ $[<7.8 \mathrm{mmol} / \mathrm{L}]$ ); G2 (admission glycaemia 140-199 mg/dL [7.8-11.0 mmol/L]); and G3 (admission glycaemia $\geq 200 \mathrm{mg} / \mathrm{dL}$ $[\geq 11.1 \mathrm{mmol} / \mathrm{L}])$. For one of the analyses, the study population was divided into four groups according to glucose level on admission (Q1: < $111 \mathrm{mg} / \mathrm{dL} ; \mathrm{Q} 2: 111-127 \mathrm{mg} / \mathrm{dL}$; Q3: 128-152 mg/dL; Q4: $\geq 153 \mathrm{mg} / \mathrm{dL}$ ).

The incidence of risk factors in the study group is presented in Table 1. The mean glucose level on admission was $7.8 \pm 2.6 \mathrm{mmol} / \mathrm{L}$, and the mean first fasting plasma glucose level was $5.6 \pm 1.0 \mathrm{mmol} / \mathrm{L}$. Group G1 consisted of $80(42.1 \%)$, G2 of 94 (49.5\%), and G3 of 16 (8.4\%) patients.

Table 1. Incidence of risk factors in study group

\begin{tabular}{lc}
\hline Obesity & $29(15.3 \%)$ \\
Hypertension & $132(69.5 \%)$ \\
Dyslipidaemia & $97(51.1 \%)$ \\
Smokers & $103(54.2 \%)$ \\
Previous myocardial infarction & $66(34.7 \%)$ \\
Impaired fasting glucose & $15(7.9 \%)$ \\
Impaired glucose tolerance & $62(32.6 \%)$ \\
Metabolic syndrome & $120(63.2 \%)$
\end{tabular}


During the observational period (the mean follow-up was $48.3 \pm 13.9$ months) occurrence of diabetes was assessed during ambulatory visit (based on interview, available medical documentation, or OGTT performed in persons without previously post-discharge diagnosis of diabetes) or on the basis of information received from family (for patients who died after hospital discharge). We did not diagnose diabetes on the basis of $\mathrm{HbA}_{1 \mathrm{C}}$ value because this parameter was not considered by PDA or EASD as a diagnostic tool.

This study complies with the Declaration of Helsinki and was approved by the Ethics Committee of Jagiellonian University. Informed consent was obtained from each patient. Source of founding - Collegium Medicum UJ statutory research grant.

\section{Statistical analysis}

Descriptive statistics were measured in order to summarise the collected data. The continuous variables were reported as median and interquartile or as means and standard deviations. The categorical variables were reported as numbers and percentages. To determine if variables had normal distribution the Shapiro-Wilk test was implemented, and Levene's test was used to assess the equality of variance in samples. Normally-distributed continuous variables were compared using Student's t-test for dependent or independent samples as appropriate. The non-parametric Mann-Whitney $U$ test or the Wilcoxon signed-rank test were used to compare non-normally distributed variables. Pearson's $\chi^{2}$ test was applied to the categorical variables. Logistic regression was used to assess the factors that can have an influence on the end-point. For significant factors odds ratio (OR) and 95\% confidence interval $(\mathrm{Cl})$ were measured. To assess the relation between continuous variables Pearson's correlation coefficient (r) was applied. A p value $<0.05$ was considered statistically significant. Statistical analysis was performed using Statistica PL software version 8.0.

\section{RESULTS}

After discharge 42 (22.1\%) participants of the study died (information about metabolic status was received from family members).

The mean glucose level on admission in the groups G1, G2, and G3 is presented in Table 2. Patients with higher admission glucose level were older, more frequently had STEMI, metabolic syndrome, and IGT, and also had lower LVEF. In subjects with higher admission glucose the maximal levels of troponin I were higher, as well as maximal values of creatine phosphokinase; a trend towards higher maximal values of creatine kinase-MB was also observed. The highest level of first fasting glycaemia was observed in group G3. There were no significant differences in body mass index, estimated glomerular filtration rate, white blood cell count, cardiovascular risk factors, or IFG incidence between the mentioned groups (Table 2).
After follow-up (mean $48.2 \pm 13.9$ months) 15 new cases of diabetes were diagnosed ( $7.9 \%$ of the whole group). Occurrence of diabetes during the observational time was more frequently found in patients with higher glucose level on admission (Fig. 1). In the group with newly diagnosed diabetes the mean glucose level on admission was also significantly higher ( $9.4 \pm 4.3$ vs. $7.7 \pm 2.3 \mathrm{mmol} / \mathrm{L}, \mathrm{p}=0.0125)$. IFG was diagnosed during ambulatory visit among 20 of 127 patients, and IGT in 21 (16.5\%). There were no proven significant differences in the occurrence of IFG and ICT between groups G1, G2, and G3. There was only a tendency towards a higher percentage of IFG in G3 compared to the other groups (Table 3).

Among 77 patients with diagnosed IFG or IGT during hospitalisation, diabetes occurred in nine $(11.7 \%)$, IGT in 13 (16.9\%), and IFG in three (3.9\%) patients during follow-up.

Among groups Q1-Q4, a tendency towards a higher proportion of newly diagnosed diabetes in long-term observation was seen in groups with higher glycaemia on admission (Q1: 4.6\%; Q2: 4.8\%; Q3: 7.4\%; and Q4: 13.2\%, respectively). However, there was no statistically significant difference between groups.

The results of logistic regression model prove two independent risk factors for diabetes development in long-term follow up: glucose level on admission (considered as continuous variable) with OR $1.2(95 \% \mathrm{Cl} 1.0-1.4, \mathrm{p}=0.03)$ and occurrence of IGT with OR 3.6 (95\% Cl 1.0-12.0, p = 0.04). Other elements in this model of logistic regression were not proven as risk factors of diabetes development in long-term observation (Fig. 2).

\section{DISCUSSION}

Despite a number of publications concerning acute hyperglycaemia, a precise and widely acceptable biochemical definition of acute hyperglycaemia has not been established yet. In studies evaluating the impact of acute hyperglycaemia the threshold level of hyperglycaemia has varied between 120 and $200 \mathrm{mg} / \mathrm{dL}(6.7-11.1 \mathrm{mmol} / \mathrm{L})$ for glycaemia on admission, and between 110 and $144 \mathrm{mg} / \mathrm{dL}(6.1-8.0 \mathrm{mmol} / \mathrm{L})$ for the first fasting glucose level [2]. There is also no clear position of scientific societies in this area. The guidelines of PDA define "relative hyperglycaemia" as glycaemia > $140 \mathrm{mg} / \mathrm{dL}$ $(7.8 \mathrm{mmol} / \mathrm{L})$ in patients without previously diagnosed diabetes and $>180 \mathrm{mg} / \mathrm{dL}$ (10.0 mmol/L) in diabetics [14]. American guidelines published in 2011 recommend that hyperglycae$\mathrm{mia} \geq 180 \mathrm{mg} / \mathrm{dL}(10.0 \mathrm{mmol} / \mathrm{L})$ in diabetics requires hypoglycaemic treatment [16]. The threshold of hyperglycaemia in non-diabetics was not clearly specified in these guidelines [16]. Our study population was divided into three groups, and glucose levels on admission of $140 \mathrm{mg} / \mathrm{dL}$ (7.8 mmol/L) and $200 \mathrm{mg} / \mathrm{dL}(11.1 \mathrm{mmol} / \mathrm{L})$ were taken as cut-off points. Such a division has also been used by other investigators [2, 8, 9]. 
Table 2. In-hospital demographic, clinical, and laboratory data

\begin{tabular}{|c|c|c|c|c|}
\hline & Group1 $(n=80)$ & Group $2(n=94)$ & Group $3(n=16)$ & $\mathbf{P}$ \\
\hline Age [years] & $59.3 \pm 11.5$ & $63.9 \pm 11.7$ & $68.7 \pm 13.1$ & $0.0030^{a, c}$ \\
\hline Women & $13(16.3 \%)$ & $22(23.4 \%)$ & $3(18.8 \%)$ & 0.494 \\
\hline STEMI & $60(75.0 \%)$ & $84(89.4 \%)$ & $14(87.5 \%)$ & $0.0369^{a}$ \\
\hline NSTEMI & $20(25.0 \%)$ & $10(10.6 \%)$ & $2(12.5 \%)$ & $0.0369^{a}$ \\
\hline Body mass index $\left[\mathrm{kg} / \mathrm{m}^{2}\right]$ & $25.9 \pm 3.3$ & $27.0 \pm 3.8$ & $27.3 \pm 2.7$ & 0.124 \\
\hline Obesity & $10(12.5 \%)$ & $17(18.9 \%)$ & $2(12.5 \%)$ & 0.563 \\
\hline Metabolic syndrome & $44(55.0 \%)$ & $55(58.5 \%)$ & $16(100.0 \%)$ & $0.003^{b, c}$ \\
\hline Smokers & $46(57.5 \%)$ & $50(53.2 \%)$ & $7(43.8 \%)$ & 0.579 \\
\hline Hypertension & $50(62.5 \%)$ & $71(75.5 \%)$ & $11(68.8 \%)$ & 0.177 \\
\hline Dyslipidaemia & $44(55.0 \%)$ & $48(51.6 \%)$ & $5(31.3 \%)$ & 0.216 \\
\hline Previous myocardial infarction & $11(13.8 \%)$ & $20(21.3 \%)$ & $3(18.6 \%)$ & 0.433 \\
\hline LVEF [\%] & $51.1 \pm 7.7$ & $50.6 \pm 9.7$ & $41.0 \pm 12.4$ & $0.0038^{a, b}$ \\
\hline Troponin I max [ng/mL] & $10.8 \pm 13.1$ & $14.2 \pm 15.5$ & $27.2 \pm 17.9$ & $0.0296^{b}$ \\
\hline CPK max [U/L] & $1670.3 \pm 2185.2$ & $2228.9 \pm 2773.3$ & $3970.7 \pm 3864.1$ & $0.0402^{b}$ \\
\hline CK-MB max [U/L] & $200.8 \pm 261.8$ & $237.8 \pm 247.2$ & $496.6 \pm 490.9$ & 0.051 \\
\hline eGFR $\left[\mathrm{mL} / \mathrm{min} / 1.73 \mathrm{~m}^{2}\right]$ & $80.3 \pm 24.8$ & $73.1 \pm 24.8$ & $63.4 \pm 24.7$ & 0.228 \\
\hline WBC [thousand/mm³] & $10.4 \pm 3.3$ & $10.7 \pm 3.4$ & $14.7 \pm 4.4$ & 0.199 \\
\hline Admission glucose level [mmol/L] & $5.9 \pm 0.7$ & $8.9 \pm 0.9$ & $14.2 \pm 3.0$ & $<0.0001^{a, b, c}$ \\
\hline First fasting glucose level [mmol/L] & $5.3 \pm 0.7$ & $5.8 \pm 1.0$ & $6.3 \pm 1.6$ & $<0.0001^{b, c}$ \\
\hline Impaired fasting glucose & $9(11.2 \%)$ & $6(6.4 \%)$ & $0(0.0 \%)$ & 0,131 \\
\hline Impaired glucose tolerance & $20(25.0 \%)$ & $33(35.1 \%)$ & $9(56.2 \%)$ & $0.0399^{c}$ \\
\hline
\end{tabular}

${ }^{a} p<0.05$ for Group 1 vs. Group 2; ${ }^{b} p<0.05$ for Group 2 vs. Group 3; ${ }^{c} p<0.05$ for Group 1 vs. Group 3; CK-MB - isoenzyme of creatine kinase with muscle and brain subunits; CPK — creatine phosphokinase; eGFR - estimated glomerular filtration rate; LVEF — left ventricular ejection fraction; NSTEMI — non-ST-segment elevation myocardial infarction; STEMI — ST-segment elevation myocardial infarction; WBC — white blood cell count

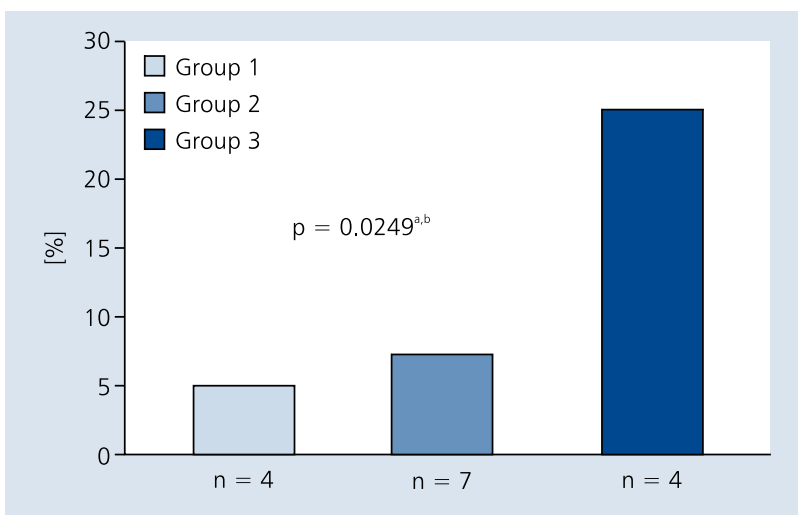

Figure 1. New incidences of diabetes in long-term observation; ${ }^{a} p<0.05$ for Group 2 vs. Group 3; ${ }^{b} p<0.05$ for Group 1 vs. Group 3

There are limited data regarding the relation between acute hyperglycaemia in patients with ACS and the frequency of new onset of diabetes in long-term observation. In our study, based on an unselected, consecutive cohort of patients with $\mathrm{MI}$, in which diabetes was excluded on the basis of OGTT performed during the index hospitalisation, newly diagnosed diabetes during a four-year follow-up period occurred more often in patients with acute hyperglycaemia. On the basis of logistic regression it was proven that admission glucose level and diagnosis of IGT during hospitalisation are independent risk factors of diabetes development in long-term observation. To our knowledge, so far there has only been one study published assessing the relation between hyperglycaemia in patients with ACS and the occurrence of new incidences of diabetes in long-term observation [17]: the KORA register database including 1293 non-diabetic patients with MI. The study population was divided into four groups according to glucose level on admission (Q1: < $111 \mathrm{mg} / \mathrm{dL} ; \mathrm{Q} 2$ : 111-127 mg/dL; Q3: 128-152 mg/dL; and Q4: $\geq 153 \mathrm{mg} / \mathrm{dL}$ ). The mean follow-up was 4.7 years, and during this period diabetes was diagnosed in 108 subjects. The authors presented strong correlation between admission glucose level and the frequency of newly diagnosed diabetes in long-term observation. Compared to acute MI patients with blood glucose level on admission of $111 \mathrm{mg} / \mathrm{dL}$ (group Q1), patients with levels $\geq 153 \mathrm{mg} / \mathrm{mL}$ (group Q4) had a 2.6-fold higher risk of diabetes [17]. When we also divided the study population into four groups in accordance with the cut-off point in the KORA registry, in groups with higher glycaemia diabetes was 
Table 3. Follow-up incidence of pre-diabetic states

\begin{tabular}{lcccc|} 
& Group 1 $(\mathbf{n}=\mathbf{5 5})$ & Group 2 (n= 61) & Group 3 (n= 11) & P \\
\hline Impaired fasting glucose (IFG) & $5(9.1 \%)$ & $12(19.7 \%)$ & $3(27.3 \%)$ & 0.156 \\
Impaired glucose tolerance (IGT) & $9(16.4 \%)$ & $11(18.0 \%)$ & $1(9.1 \%)$ & 0.737 \\
IFG or IGT & $14(25.4 \%)$ & $23(37.7 \%)$ & $4(36.4 \%)$ & 0.349 \\
\hline
\end{tabular}

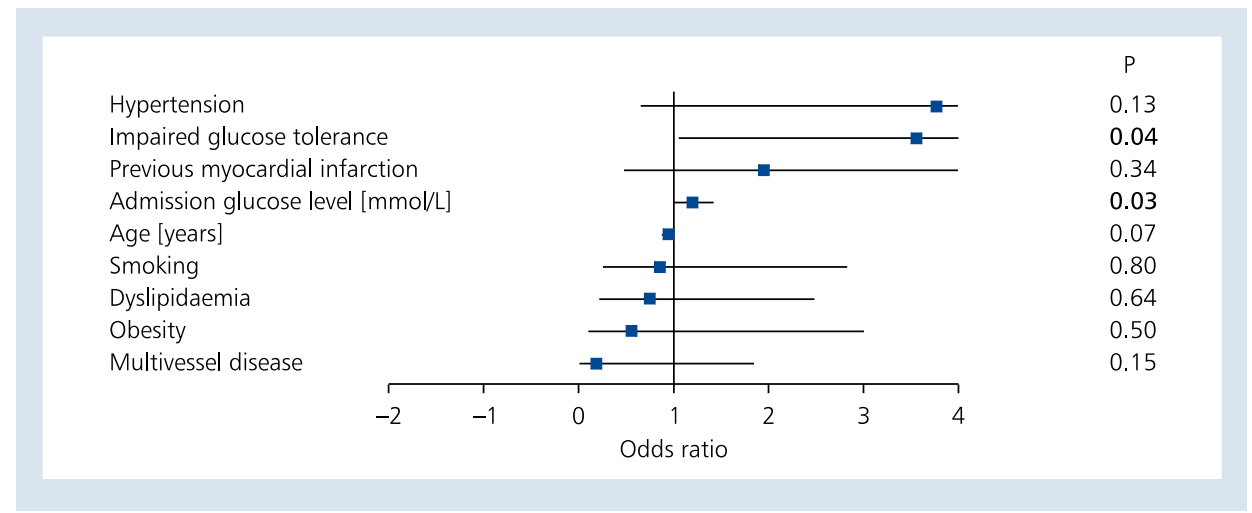

Figure 2. Risk factors of diabetes development in long-term observation. To summarise the results of logistic regression odds ratio (squares), 95\% confidence interval (lines) and statistical significance (p) are presented (forest plot)

diagnosed more often in long-term observation. However, there was only a statistically non-significant tendency.

The results of our study and the KORA registry suggest that acute hyperglycaemia in patients with ACS could be an early marker of glucose homeostasis disturbances, which after a longer period may reach the diabetes criteria. Impaired glucose metabolism - asymptomatic and entirely compensated in stable condition - in the early phase of $\mathrm{MI}$, during severe stress reaction when compensation is impossible, may elicit hyperglycaemia, but after the acute phase and relative stabilisation phase may subside and not allow diagnosis of impaired glucose metabolism in the peri-infarction period. However, in a longer observation period, due to increasing insulin resistance and progressive decrease in insulin excretion, these patients could have a higher probability of diabetes development.

It is important to underline that, in our study, patients with higher glucose level on admission had more frequent metabolic syndrome and IGT in hospital. A tendency towards higher proportion of patients with IFG was also observed in this group.

Recommendations for long-term management of patients with hyperglycaemia in the acute phase of ACS are not yet specified. Nevertheless, data indicating the relation between higher admission glucose level and increased incidence of diabetes in subjects with ACS have important clinical implications. Particularly in this group, non-pharmacological interventions, such as regular physical activity, proper diet, and loss of weight should be strictly implemented because they are of great importance in the reduction of progression and treatment of impaired glucose metabolism.

Although the guidelines do not separately mention subjects with acute hyperglycaemia, it is recommended that in patients with higher risk, including those with cardiovascular diseases, diabetes screening tests should be repeated [14-16]. These tests have particular significance in patients with acute hyperglycaemia during $\mathrm{Ml}$ as they enable early diagnosis of impaired glucose metabolism and implementation of optimal treatment.

\section{Limitations of the study}

The present study has several limitations that need to be considered. The number of patients studied (especially patients with NSTEMI) is limited. Due to the observational nature of this study, the possibility of selection bias and/or residual confounding from unknown or unmeasured covariates cannot be excluded. Our study is a single-centre observational study, so we should be cautious about hypothesising the mechanisms involved and the generalisability of our conclusions to other populations. According to guidelines, it is recommended to use a specific screening tool in patients with cardiovascular risk factors to assess the risk of diabetes development in the future. Due to the partially retrospective character of our study and the lack of some data (dietary habits, physical activity, family history, etc.), we did not use any risk score for the risk of diabetes development. Diabetes diagnosis at follow-up in our study depended on the basis of OGTT performed during ambulatory visit or information received from the family (for 
patients who died after hospital discharge) that could have affected the findings. We did not diagnose diabetes on the basis of $\mathrm{HbA}_{1 \mathrm{C}}$ values as this parameter was not considered by the PDA as a diagnostic tool.

\section{CONCLUSIONS}

Patients with higher glucose level during acute phase of $\mathrm{MI}$ have higher risk of diabetes incidence in the future. In subjects suffering from $\mathrm{Ml}$ the strict screening of glucose disturbance should be applied.

\section{Conflict of interest: none declared}

\section{References}

1. Kosiborod M, Deedwania P. An overview of glycemic control in the coronary care unit with recommendations for clinical management. J Diabetes Sci Technol, 2009; 3: 1342-1351. doi: 10.1177/193229680900300614.

2. Szynal S, Zabojszcz M, Kosiniak-Kamysz W, Bryniarski L. Acute hyperglycaemia in acute coronary syndromes in patients without diabetes mellitus. Kardiodiabetologia, 2008; 3: 5-12.

3. Little RA, Frayn KN, Randall PE et al. Plasma catecholamines in the acute phase of the response to myocardial infarction. Arch Emerg Med, 1986; 3: 20-27.

4. Sewdarsen M, Jialal I, Vythilingum S et al. Stress hyperglycemia is a predictor of abnormal glucose tolerance in Indian patients with acute myocardial infarction. Diabetes Res, 1987; 6: 47-49.

5. Oswald GA, Smith CC, Betteridge DJ, Yudkin JS. Determinants and importance of stress hyperglycaemia in non-diabetic patients with myocardial infarction. Br Med J (Clin Res Ed), 1986; 293: 917-922.

6. Capes SE, Hunt D, Malmberg K, Gerstein HC. Stress hyperglycaemia and increased risk of death after myocardial infarction in patients with and without diabetes: a systematic overview. Lancet, 2000; 355: 773-778. doi:10.1016/S0140-6736(99)08415-9.

7. Foo K, Cooper J, Deaner A, et al. A single serum glucose measurement predicts adverse outcomes across the whole range of acute coronary syndromes. Heart, 2003; 89: 512 516. doi:10.1136/heart.89.5.512.

8. Gasior M, Stasik-Pres G, Pres D et al. Relationship between blood glucose on admission and prognosis in patients with acute myocardial infarction treated with percutaneous coronary intervention. Kardiol Pol, 2007; 65: 1031-1040.
9. Dziewierz A, Giszterowicz D, Siudak Z et al. Admission glucose level and in-hospital outcomes in diabetic and non-diabetic patients with acute myocardial infarction. Clin Res Cardiol, 2010; 99: 715-721. doi: 10.1007/s00392-010-0175-1.

10. Bryniarski L, Terlecki M, Bednarek et al. The effects of acute hyperglycaemia on the in-hospital and long-term prognosis in patients with an acute coronary syndrome: a pilot study. Kardiol Pol, 2011; 69, 8: 774-781.

11. Van de Werf F, Bax J, Betriu A et al. ESC Committee for Practice Guidelines (CPG). Management of acute myocardial infarction in patients presenting with persistent ST segment elevation: the Task Force on the Management of ST-Segment Elevation Acute Myocardial Infarction of the European Society of Cardiology. Eur Heart J, 2008; 29: 2909-2945. doi: 10.1093/eurheartj/ehn416.

12. Bassand JP, Hamm CW, Ardissino D et al. Task Force for Diagnosis and Treatment of Non-ST-Segment Elevation Acute Coronary Syndromes of European Society of Cardiology. Guidelines for the diagnosis and treatment of non-ST-segment elevation acute coronary syndromes. Eur Heart J, 2007; 28: 1598-1660. doi: 10.1093/eurheartj/ehm161.

13. Grundy SM, Brewer HB, Cleeman JI et al. Definition of metabolic syndrome: report of the National Heart, Lung, and Blood Institute/American Heart Association conference on scientific issues related to definition. Arterioscler Thromb Vasc Biol. 2004; 24: e13-e18. doi: 10.1161/01.ATV.0000111245.75752.C6.

14. Clinical recommendations for the management of diabetes 2011. Consensus of the Polish Diabetes Society. Diabetol Prakt, 2011; 12 (suppl. A): 1-50.

15. The American Diabetes Association. Executive summary: Standards of medical care in diabetes 2011. Diabetes Care, 2011; 34 (suppl. 1): S4-S10. doi: 10.2337/dc11-S004.

16. Ryden L, Standl E, Bartnik M et al. Task Force on Diabetes and Cardiovascular Diseases of the European Society of Cardiology (ESC); European Association for the Study of Diabetes (EASD). Guidelines on diabetes, pre-diabetes, and cardiovascular diseases: executive summary. The Task Force on Diabetes and Cardiovascular Diseases of the European Society of Cardiology (ESC) and of the European Association for the Study of Diabetes (EASD). Eur Heart J, 2007; 28: 88-136. doi: 10.1093/eurheartj/ehl260.

17. Meisinger C, Beck J, Heier M et al. KORA Study Group. Myocardial infarction and incidence of type 2 diabetes mellitus. Is admission blood glucose an independent predictor for future type 2 diabetes mellitus? Am Heart J, 2010; 159: 258-263. doi: 10.1016/j.ahj.2009.11.027. 


\title{
Ryzyko rozwoju cukrzycy w obserwacji odległej u pacjentów z zawałem serca i hiperglikemią ostrej fazy
}

\author{
Michał Terlecki, Leszek Bryniarski, Agnieszka Bednarek, Maryla Kocowska, Kalina Kawecka-Jaszcz, \\ Danuta Czarnecka \\ I Klinika Kardiologii i Elektrokardiologii Interwencyjnej oraz Nadciśnienia Tętniczego, Uniwersytet Jagielloński, Collegium Medicum, Kraków
}

\section{Streszczenie}

Wstęp: Ostrej reakcji stresowej, którą dla organizmu może być zawał serca (MI) lub udar mózgu, towarzyszy przejściowy wzrost stężenia glukozy we krwi. Z dotychczas opublikowanych badań wynika, że u pacjentów z MI hiperglikemia ostrej fazy jest niekorzystnym czynnikiem rokowniczym zarówno w obserwacji krótko-, jak i długoterminowej. Brakuje jednak danych oceniających związek między hiperglikemią ostrej fazy u chorych z MI a częstością występowania nowych przypadków cukrzycy w obserwacji odległej.

Cel: Celem badania była ocena związku między stężeniem glukozy podczas ostrej fazy MI a częstością występowania nowych przypadków cukrzycy w obserwacji odległej.

Metody: Do badania włączono 272 pacjentów hospitalizowanych w latach 2004-2007 w I Klinice Kardiologii i Nadciśnienia Tętniczego Szpitala Uniwersyteckiego w Krakowie z powodu MI, bez uprzednio rozpoznanej cukrzycy. Każdemu uczestnikowi badania oznaczono stężenie glukozy we krwi przy przyjęciu i wykonano test obciążenia glukozą (OGTT). Wykluczono pacjentów, którzy zmarli w czasie hospitalizacji oraz chorych, u których na podstawie wykonanego pod koniec hospitalizacji OGTT rozpoznano cukrzycę, opierając się na wytycznych Polskiego Towarzystwa Diabetologicznego. Ostatecznie do badania włączono 190 osób. Chorych podzielono na grupy w zależności od stężenia glukozy przy przyjęciu (G1: stężenie glukozy przy przyjęciu < 7,8 mmol/l, tj. < 140 mg/dl; G2: stężenie glukozy przy przyjęciu: 7,8-11,0 mmol/l, tj. 140-199 mg/dl; G3: stężenie glukozy przy przyjęciu $\geq 11,1 \mathrm{mmol} / \mathrm{l}, \mathrm{tj}$. $\geq 200 \mathrm{mg} / \mathrm{dl}$ ). Po okresie obserwacji (48,3 \pm 13,9 miesiąca) poszukiwano nowych przypadków cukrzycy u uczestników badania, wykonując OGTT (o ile nie rozpoznano cukrzycy przed wizytą kontrolną). W przypadku osób, które zmarły w okresie obserwacji, uzyskiwano informację na temat rozpoznania cukrzycy od ich rodzin.

Wyniki: Liczebność grup G1, G2, G3 wyniosła odpowiednio 80 (42,1\%), 94 (49,5\%) i 16 (8,4\%) pacjentów. Średni wiek uczestników badania wynosił $61,3 \pm 11,3$ roku. U 158 (83,2\%) chorych rozpoznano MI z uniesieniem załamka ST, a u 32 (16,8\%) MI bez uniesienia załamka ST. Po okresie obserwacji wynoszącej 48,2 \pm 13,9 miesiąca zanotowano 15 nowych przypadków cukrzycy (7,9\% spośród całej obserwowanej grupy). Większą częstość nowych przypadków cukrzycy stwierdzono u chorych, którzy mieli wyższe stężenia glukozy przy przyjęciu (5,0\% vs. 7,4\% vs. 25,0\%; p = 0,0249). W modelu regresji logistycznej wykazano dwa niezależne czynniki ryzyka rozwoju cukrzycy w obserwacji odległej: stężenie glukozy przy przyjęciu do szpitala oceniane jako zmienna ciągła (OR 1,2; 95\% Cl 1,0-1,4; $\mathrm{p}=0,03$ ) i nieprawidłowa tolerancja glukozy stwierdzona w czasie hospitalizacji (OR 3,6; 95\% Cl 1,0-12,0; $\mathrm{p}=0,04$ ).

Wnioski: Chorzy z wyższymi stężeniami glukozy w ostrej fazie MI są bardziej narażeni na ryzyko rozwoju cukrzycy w przyszłości. Ścisłe monitorowanie zaburzeń gospodarki węglowodanowej po przebyciu MI u tych pacjentów jest szczególnie istotne. Słowa kluczowe: hiperglikemia, cukrzyca, zawał serca

Kardiol Pol 2015; 73, 8: 606-612

\section{Adres do korespondencji:}

lek. Maryla Kocowska, I Klinika Kardiologii i Elektrokardiologii Interwencyjnej oraz Nadciśnienia Tętniczego, Uniwersytet Jagielloński, Collegium Medicum, ul. Kopernika 17, 31-501 Kraków, e-mail: marylak@gmail.com

Praca wpłynęła: 11.01.2014 r. Zaakceptowana do druku: 26.02.2015 r. $\quad$ Data publikacji AoP: 25.03.2015 r. 